\title{
READINESS OF FINAL YEAR NURSING STUDENTS FOR THE PROFESSION AND THE AFFECTING FACTORS: EASTERN BLACK SEA REGION SAMPLE Hacer GÖK UĞUR ${ }^{1}$, Oya Sevcan ORAK ${ }^{2}$, Ahmet Talha TEKGÜL ${ }^{3}$
}

\author{
ABSTRACT
}

Objectives: This study aims to examine the readiness of final year nursing students for their profession and the affecting factors. Method: The population of this descriptive study consisted of 440 final year nursing students at five different universities in Turkey's Eastern Black Sea Region. The sample consisted of 313 students. The data were gathered between January and February, 2015. The researchers prepared and used a questionnaire form in line with the literature to collect the data. The data were evaluated with SPSS 20.0 statistical software using descriptive statistics, the chi-square test and binary logistic regression.

Results: Of the students, $56.2 \%$ said that they were ready for the profession. There were statistically significant correlations between students' readiness for the profession and their having selected the profession willingly, being happy to have selected the profession, feeling safe in the profession, self-efficacy for the profession, feeling anxiety concerning working life and thoughts about nursing $(p<0.05)$. There is statistically significant correlation between students' readiness for nursing and their finding practical training adequate in undergraduate study $(p<0.05)$.

Conclusion: This study found that half of the students were ready for the profession. Their having selected the profession willingly, being happy to have selected the profession, self-efficacy for the profession and feeling anxiety concerning working life were predictor variables for readiness.

Keywords: Nursing students; Nursing; Readiness.

\section{Hemşirelik Son Sınıf Öğrencilerinin Mesleğe Hazir Bulunuşluklari Ve Etkileyen Faktörler: Doğu Karadeniz Bölgesi Örneği \\ ÖZET}

Amaç: Bu çalışma hemşirelik son sınıf ögrencilerinin mesleki hazır bulunuşluklarını ve etkileyen faktörleri belirlemek amacıyla yapılmıştır.

Yöntem: Tanımlayıcı olarak yapılan çalışmanın evrenini Türkiye’de Doğu Karadeniz Bölgesi'nde beş üniversitede son sınıfta okuyan 440 hemşirelik öğrencisi, örneklemi ise 313 öğrenci oluşturmuştur. Araştırmanın verileri Ocak-Şubat 2015 tarihleri arasında toplanmıştır. Verilerin toplanmasında araştırmacılar tarafindan literature doğrultusunda hazırlanan anket formu kullanılmıştır. Veriler SPSS 20 istatistik paket programında tanımlayıcı istatistikler, ki kare testi ve binary logistik regresyon analizi ile değerlendirilmiştir.

Bulgular: Araştırmada öğrencilerin \%56.2 sinin hemşirelik mesleğine hazır bulunduğu belirlenmiştir. Öğrencilerin hemşirelik mesleğini isteyerek seçme, mesleği seçtiği için mutlu olma, meslekte kendini güvende hissetme, meslek için kendini yeterli hissetme, çalışma hayatıyla ilgili kaygl yaşama ve hemşirelik yapmayı düşünme durumlarl ile hemşirelik mesleğine hazır bulunuşlukları arasında istatistiksel olarak anlamlı bir iliş̧i olduğu bulunmuştur ( $p<0.05$ ). Öğrencilerin lisans eğitimi uygulamalarını yeterli bulma durumları ile hemşirelik mesleğine hazır bulunuşlukları arasında istatistiksel olarak anlamlı bir ilişki olduğu belirlenmiştir ( $p<0.05$ ).

Sonuç: Araştırmada öğrenci hemşirelerin yarısının mesleğe hazır bulunduğu ve mesleğini isteyerek seçme, mesleği seçtiği için mutlu olma, meslek için kendini yeterli hissetme ve çalışma hayatıyla ilgili kaygl yaşama durumlarının mesleğe hazır bulunuşlukta yordayıc değişkenler olduğu belirlenmiştir.

Anahtar Kelimeler:Hemşirelik öğrencisi; Hemşirelik; Hazır bulunuşluk.

\section{DOI:10.47115/jshs.770942}

${ }^{1}$ Ordu Üniversitesi Sağlık Bilimleri Fakültesi, Hemşirelik Bölümü, Ordu, Türkiye

${ }^{2}$ Ondokuz Mayıs Üniversitesi Sağlık Bilimleri Fakültesi, Hemşirelik Bölümü, Samsun, Türkiye

${ }^{3}$ Darende Hulusi Efendi Devlet Hastanesi, Malatya, Türkiye

Sorumlu Yazar: Oya Sevcan ORAK, email: oysev@ hotmal.com

Yazar Notu: Bu çalışma, 14.Ulusal Hemşirelik Öğrencileri Kongresinde (22-26 Nisan 2015, Kayseri) sözel bildiri olarak sunulmuştur. 


\section{INTRODUCTION}

Readiness includes the physiological and psychological preparation needed to exhibit behaviors and competencies (Topses, 2003). Readiness for nursing means being able to provide safe patient care, to be familiar with the tools and equipment for nursing practices, and to have certain special and common knowledge, skills, thinking and management to fulfill nursing role (Wolff et al., 2010; Casey et al., 2011). Preparing nursing students for today's rapidly developing and changing health care environment is very important (Duchscher, 2008). Students' readiness for nursing is influenced by educational, personal, internal and external factors (Porter et al, 213; Jarvinen et al, 2018). Studies indicate that clinic practical training during undergraduate education affects readiness (Wolff et al., 2010 Casey et al., 2011; Jarvinen et al., 2018). Nursing students have to master clinical skills throughout their education to provide competent and safe care. It is important for students to acquire clinical experience during their undergraduate education, and it is difficult for them to master the necessary skills if they do not have opportunities to do so (Şengül, 2010). The problems that the students face, especially in clinical practical training, cause a sense of professional inadequacy and the desire to quit the profession. Therefore, it is very important to determine students' needs before they graduate (Brown, 2016). In addition, it is stated that the lack of clinical skills, communication problems and anxiety about working in a permanent job affect the readiness of nursing students (Missen et al., 2015).However, the views of nursing students about the profession and feeling safe in the profession affect their readiness (Jarvinen et al., 2018; Cooper et al., 2005; Bowdoin, 2014; Morrell and Ridgway, 2014; Numminen et al., 2015; Usher et al., 2015; Woods et al., 2015; Christensen, 2016). Another factor that affects the readiness of students is their self-confidence about bearing the responsibilities imposed by the profession (Duchscher, 2008). It is important to know students' readiness levels and the factors that affect them to ensure effective teaching and learning in nursing (Brown, 2016). Determining the factors that affect readiness and taking precautions are important for nurses to provide a quality and effective service after graduation (Casey et al., 2011). The factors that affect nursing students' readiness may differ by country or culture. Therefore, studies about the subject should be conducted in different countries (Jarvinen et al., 2018). The need to determine the factors that affect the self-confidence of final year nursing students has been emphasized (Porter et al., 2013). Conducting studies to show students' readiness for nursing is important for organizing nursing training programs before graduation (Brown, 2016). This study was conducted to determine final year nursing students' readiness and factors that affect it.

\section{Research Questions}

What are the perceptions of final year nursing students about their readiness for the profession?

What are the factors that affect final year nursing students' readiness?

\section{Methods}

\section{Design and Sample}

The population of this descriptive study consisted of 440 final year nursing students at five different universities in Turkey's Eastern Black Sea Region. No sampling method was used, and the entire population was considered as sample (Erdoğan et al., 2014). The study was completed with 313 students who agreed to participate. The participation rate was $71.13 \%$. The data were collected between January and February 2015.

\section{Ethical Considerations}

The research was conducted in compliance with the Helsinki Declaration. Written permission were obtained from the nursing departments of the universities, and verbal consent from the students was obtained.

\section{Instrumentation}

The researchers collected the data in line with the literature using a questionnaire form with three sections (Cooper et al., 2005; Lofman et al., 2006; Nash et al., 2009; Woods et al., 2013; Ishihara et al., 2014; Yang and Jiang, 2014). The first section included nine questions about socio-demographic features (age, gender, income status, family type, parental education, place of residence, high school graduation and preference order for nursing). The second section had nine questions about students' thoughts about nursing (selecting the profession willingly, reason for selecting the profession, being happy to have selected the profession, feeling safe in the profession, self-efficacy for the profession, fear of assignments, feeling anxiety concerning working life, thoughts about nursing and readiness for nursing). The third section consisted of five questions about their undergraduate education (finding practical training adequate, doing internships, wishing to do internships, doing summer internships and wishing to do summer internships).This form was arranged in line with the recommendations of 3 experts in the field of nursing.

\section{Data Collection}

While collecting the data of the research, the data collection forms were first applied on 10 senior nursing students and within this framework, the data collection form was finalized and used. The data were collected at the five universities in face-to-face interviews that lasted between 15 and 20 minutes.

\section{Statistical Analysis}

The data were evaluated with SPSS 20.0 software using descriptive statistics, the chi-square test and binary logistic regression. The threshold for significance was $<0.05$.

\section{Limitations}

This study contains some limitations. The data of the research were collected with a questionnaire form prepared by the researchers in line with the literature. The nursing student's readiness for the profession was evaluated by their own perceptions. A scale with validity and reliability on the subject was not used. The most important limitation of this study is that the students' responses were based their own perceptions. 
Table 1. Distribution of the students' socio-demographic characteristics

\begin{tabular}{|c|c|c|c|}
\hline & & \multicolumn{2}{|c|}{$\bar{x} \pm$ SD $($ Min-Max $)$} \\
\hline \multicolumn{2}{|l|}{ Age } & \multicolumn{2}{|c|}{$22.38 \pm 1.36(21-28)$} \\
\hline \multicolumn{2}{|c|}{ Nursing Department Preference Order } & \multicolumn{2}{|c|}{$4.62 \pm 6.12(1-24)$} \\
\hline & & $\mathrm{n}$ & $\%$ \\
\hline \multirow[t]{2}{*}{ Gender } & Female & 230 & 73.5 \\
\hline & Male & 83 & 26.5 \\
\hline \multirow[t]{3}{*}{ Income Status } & Low & 30 & 9.6 \\
\hline & Middle & 269 & 85.9 \\
\hline & High & 14 & 4.5 \\
\hline \multirow[t]{3}{*}{ Family Type } & Nuclear family & 261 & 83.4 \\
\hline & Extended family & 47 & 15.0 \\
\hline & Single parent family & 5 & 1.6 \\
\hline \multirow[t]{5}{*}{ Mother's Education } & Illiterate & 36 & 11.5 \\
\hline & Literate & 47 & 15.0 \\
\hline & Primary school & 176 & 56.2 \\
\hline & High school & 44 & 14.1 \\
\hline & University & 10 & 3.2 \\
\hline \multirow[t]{5}{*}{ Father's Education } & Illiterate & 7 & 2.3 \\
\hline & Literate & 29 & 9.3 \\
\hline & Primary school & 141 & 45.0 \\
\hline & High school & 88 & 28.1 \\
\hline & University & 48 & 15.3 \\
\hline \multirow[t]{3}{*}{ Residence } & Village & 48 & 15.3 \\
\hline & District & 118 & 37.7 \\
\hline & Province & 147 & 47.0 \\
\hline \multirow[t]{5}{*}{ High School } & General high school & 167 & 53.4 \\
\hline & Medical vocational high school & 28 & 8.9 \\
\hline & Anatolian high school & 103 & 32.9 \\
\hline & Anatolian teacher high school & 6 & 1.9 \\
\hline & Vocational high school & 9 & 2.9 \\
\hline
\end{tabular}

\section{RESULTS}

The mean age of the participants was $22.38 \pm 1.36,73.5 \%$ were female, and $85.9 \%$ had middle incomes. Of them, $83.4 \%$ had nuclear families, $56.2 \%$ had mothers who had completed primary school, and $28.1 \%$ had fathers who were high school graduates. Of them, $47 \%$ had lived longest in city center, and $53.4 \%$ were general high school graduates. They had a $4.62 \pm 6.12$ mean preference order for nursing (Table 1).
Of the students, $67.7 \%$ said they selected the profession willingly, $48.9 \%$ selected it for job guarantee, and $62.9 \%$ they felt happy in the profession. Of them, $64.9 \%$ did not feel safe in the profession, $63.9 \%$ felt self-efficacy for the profession, and $60.4 \%$ had fear of assignment. Of them, $73.8 \%$ felt anxious about working life, $74.1 \%$ thought about nursing, and $56.2 \%$ felt ready for nursing (Table 2). 
Table 2. Distribution of the students' thoughts about nursing

\begin{tabular}{|c|c|c|c|}
\hline & & $\mathrm{n}$ & $\%$ \\
\hline \multirow[t]{2}{*}{ Selecting the profession willingly } & Yes & 212 & 67.7 \\
\hline & No & 101 & 32.3 \\
\hline \multirow[t]{5}{*}{ Reason for selecting the profession } & My family and friends wanted me to & 56 & 17.9 \\
\hline & It has job security & 153 & 48.9 \\
\hline & I love nursing & 59 & 18.8 \\
\hline & To be beneficial to the public & 26 & 8.3 \\
\hline & My exam score qualified me for nursing & 19 & 6.1 \\
\hline \multirow{2}{*}{$\begin{array}{l}\text { Being happy to have selected the } \\
\text { profession }\end{array}$} & Yes & 197 & 62.9 \\
\hline & No & 116 & 37.1 \\
\hline \multirow[t]{2}{*}{ Feeling safe in the profession } & Yes & 110 & 35.1 \\
\hline & No & 203 & 64.9 \\
\hline \multirow[t]{2}{*}{ Self-sufficiency for the profession } & Yes & 200 & 63.9 \\
\hline & No & 113 & 36.1 \\
\hline \multirow[t]{2}{*}{ Fear of assignment } & Yes & 189 & 60.4 \\
\hline & No & 124 & 39.6 \\
\hline \multirow{2}{*}{$\begin{array}{l}\text { Feeling anxiety concerning working } \\
\text { life }\end{array}$} & Yes & 231 & 73.8 \\
\hline & No & 82 & 26.2 \\
\hline \multirow[t]{2}{*}{ Thoughts about nursing } & Yes & 232 & 74.1 \\
\hline & No & 81 & 25.9 \\
\hline \multirow[t]{2}{*}{ Readiness for nursing } & Yes & 176 & 56.2 \\
\hline & No & 137 & 43.8 \\
\hline
\end{tabular}

Of the students, $57.5 \%$ found practical training during undergraduate education inadequate, $23.3 \%$ did internships during undergraduate education, and $73.8 \%$ wanted to do internships during undergraduate education. Of them, $48.9 \%$ did summer internships, and $77.3 \%$ did not want to do summer internships during undergraduate education (Table3). 
Table 3. Distribution of some characteristics of the students regarding undergraduate education

\begin{tabular}{|c|c|c|c|}
\hline & & $\mathbf{n}$ & $\%$ \\
\hline \multirow[t]{2}{*}{ Finding practical training adequate } & Yes & 133 & 42.5 \\
\hline & No & 180 & 57.5 \\
\hline \multirow[t]{2}{*}{ Doing internships } & Yes & 73 & 23.3 \\
\hline & No & 240 & 76.7 \\
\hline \multirow[t]{2}{*}{ Wishing to do internships } & Yes & 231 & 73.8 \\
\hline & No & 82 & 26.2 \\
\hline \multirow[t]{2}{*}{ Doing summer internships } & Yes & 153 & 48.9 \\
\hline & No & 160 & 51.1 \\
\hline \multirow[t]{2}{*}{ Wishing to do summer internships } & Yes & 71 & 22.7 \\
\hline & No & 242 & 77.3 \\
\hline
\end{tabular}

There were statistically significant correlations between students' readiness for the profession and their having selected the profession willingly, being happy to have selected the profession, feeling safe in the profession, self-efficacy for the profession, feeling anxiety concerning working life and thoughts about nursing $(\mathrm{p}<0.05)$ (Table 4$)$.
There was a statistically significant correlation between students' readiness for nursing and their finding practical training adequate in undergraduate study $(\mathrm{p}<0.05)$. There was no statistically significant correlation between students' readiness for nursing and internships and summer internships during undergraduate study ( $p>0.05$ ) (Table 5).

Table 4. Comparison of the students' readiness for nursing and their views about nursing

\begin{tabular}{|c|c|c|c|c|c|c|}
\hline & & & \multicolumn{4}{|c|}{ Readiness for the profession } \\
\hline & & & Yes & No & Total & Statistics \\
\hline \multirow{4}{*}{ Selecting the profession willingly } & Yes & $\mathrm{n}$ & 138 & 74 & 212 & \multirow{4}{*}{$\begin{array}{l}\chi^{2}=20.975 \\
\mathbf{p}=\mathbf{0 . 0 0 0}\end{array}$} \\
\hline & \multirow{3}{*}{ No } & $\%$ & 65.1 & 34.9 & 100.0 & \\
\hline & & $\mathrm{n}$ & 38 & 63 & 101 & \\
\hline & & $\%$ & 37.6 & 62.4 & 100.0 & \\
\hline \multirow[t]{4}{*}{ Being happy to have selected the profession } & Yes & $\mathrm{n}$ & 132 & 65 & 197 & \multirow{4}{*}{$\begin{array}{l}\chi^{2}=25.075 \\
\mathbf{p}=\mathbf{0 . 0 0 0}\end{array}$} \\
\hline & & $\%$ & 67.0 & 33.0 & 100.0 & \\
\hline & No & $\mathrm{n}$ & 44 & 72 & 116 & \\
\hline & & $\%$ & 37.9 & 62.1 & 100.0 & \\
\hline \multirow[t]{4}{*}{ Feeling safe in the profession } & Yes & $\mathrm{n}$ & 83 & 27 & 110 & \multirow{4}{*}{$\begin{array}{l}\chi^{2}=26.281 \\
\mathbf{p}=\mathbf{0 . 0 0 0}\end{array}$} \\
\hline & & $\%$ & 75.5 & 24.5 & 100.0 & \\
\hline & No & $\mathrm{n}$ & 92 & 111 & 203 & \\
\hline & & $\%$ & 45.3 & 54.7 & 100.0 & \\
\hline \multirow[t]{4}{*}{ Self-sufficiency for the profession } & Yes & $\mathrm{n}$ & 156 & 44 & 200 & \multirow{4}{*}{$\begin{array}{l}\chi^{2}=109.657 \\
\mathbf{p}=\mathbf{0 . 0 0 0}\end{array}$} \\
\hline & & $\%$ & 78.0 & 22.0 & 100.0 & \\
\hline & No & $\mathrm{n}$ & 19 & 94 & 113 & \\
\hline & & $\%$ & 16.8 & 83.2 & 100.0 & \\
\hline Feeling anxiety concerning working life & Yes & $\mathrm{n}$ & 112 & 115 & 227 & $\chi^{2}=14.473$ \\
\hline
\end{tabular}




\begin{tabular}{|c|c|c|c|c|c|c|}
\hline & \multirow{3}{*}{ No } & $\%$ & 49.3 & 50.7 & 100.0 & \multirow[t]{3}{*}{$p=0.000$} \\
\hline & & $\mathrm{n}$ & 63 & 23 & 86 & \\
\hline & & $\%$ & 73.3 & 26.7 & 100.0 & \\
\hline \multirow[t]{4}{*}{ Thoughts about nursing } & Yes & $\mathrm{n}$ & 141 & 90 & 231 & \multirow{4}{*}{$\begin{array}{l}\chi^{2}=9.408 \\
\mathbf{p}=\mathbf{0 . 0 0 2}\end{array}$} \\
\hline & \multirow{3}{*}{ No } & $\%$ & 61.0 & 39.0 & 100.0 & \\
\hline & & $\mathrm{n}$ & 34 & 48 & 82 & \\
\hline & & $\%$ & 41.5 & 58.5 & 100.0 & \\
\hline
\end{tabular}

The degree of relationship between dependent variables and independent variables in the logistic regression model was $36.8 \%$ according to Cox-Snell and $49.2 \%$ according to Nagelkerke. The beta value was -.239 , and the Wald value was significant at a $\mathrm{p}<0.05$ significance level concerning the regression of the readiness of some of the characteristics of the nursing regarding students' views on nursing and undergraduate education. Considering $\operatorname{Exp}(\beta)$ value $((1-.787) * 100=21.3)$ the views of the students about nursing predicted $21 \%$ of readiness for nursing. The students' having selected the profession willingly, being happy to have selected the profession, self-efficacy for the profession and feeling anxiety concerning working life were predictor variables for readiness for nursing. The other independent variables were unimportant. The students who selected the profession willingly were 1,989 times more ready for the profession than those who did not. The students who were happy to have selected the profession 2,079 times more ready for the profession than those who were not. The students who felt self-efficacy for the profession were 12,851 times more ready for the profession than those who did not. The students who had anxiety concerning working life were less ready for nursing by a factor of 0.486 (Table 6).

Table 5. Comparison of certain characteristics of the students' undergraduate education and their readiness for the profession

\begin{tabular}{|c|c|c|c|c|c|c|}
\hline & & & \multicolumn{4}{|c|}{ Readiness for the profession } \\
\hline & & & Yes & No & Total & Statistics \\
\hline \multirow[t]{4}{*}{ Finding practical training adequate } & Yes & $\mathrm{n}$ & 87 & 46 & 133 & \multirow{4}{*}{$\begin{array}{l}X^{2}=8.473 \\
\mathbf{p}=\mathbf{0 . 0 0 4}\end{array}$} \\
\hline & \multirow{3}{*}{ No } & $\%$ & 65.4 & 34.6 & 100.0 & \\
\hline & & $\mathrm{n}$ & 88 & 92 & 180 & \\
\hline & & $\%$ & 48.9 & 51.1 & 100.0 & \\
\hline \multirow[t]{4}{*}{ Doing internships } & Yes & $\mathrm{n}$ & 46 & 27 & 73 & \multirow{4}{*}{$\begin{array}{l}X^{2}=1.949 \\
\mathrm{p}=0.163\end{array}$} \\
\hline & \multirow{3}{*}{ No } & $\%$ & 63.0 & 37.0 & 100.0 & \\
\hline & & $\mathrm{n}$ & 129 & 111 & 240 & \\
\hline & & $\%$ & 53.8 & 46.2 & 100.0 & \\
\hline \multirow[t]{4}{*}{ Doing summer internships } & \multirow{2}{*}{ Yes } & $\mathrm{n}$ & 83 & 70 & 153 & \multirow{4}{*}{$\begin{array}{l}X^{2}=0.335 \\
\mathrm{p}=0.562\end{array}$} \\
\hline & & $\%$ & 54.2 & 45.8 & 100.0 & \\
\hline & \multirow{2}{*}{ No } & $\mathrm{n}$ & 92 & 68 & 160 & \\
\hline & & $\%$ & 57.5 & 42.5 & 100.0 & \\
\hline
\end{tabular}


Samsun Sağ Bil Der, 2020;5(2):143-151

Table 6. Regression analysis of students' readiness for the profession and certain characteristics

\begin{tabular}{lccccccc}
\hline & $B$ & S.E. & Wald & SD & p Exp(B) \\
\cline { 1 - 4 } Selecting the profession willingly & .688 & .336 & 4.200 & 1 & 0.040 & 1.989 \\
\hline Being happy to have selected the profession & .732 & .343 & 4.550 & 1 & 0.033 & 2.079 \\
\hline Feeling safe in the profession & .504 & .326 & 2.380 & 1 & 0.123 & 1.655 \\
\hline Self-sufficiency for the profession & 2,553 & .322 & 62.837 & 1 & 0.000 & 12.851 \\
\hline Feeling anxiety concerning working life & -.722 & .361 & 3.993 & 1 & 0.046 & 0.486 \\
\hline Thoughts about nursing & .269 & .377 & 0.509 & 1 & 0.476 & 1.309 \\
\hline Finding practical training adequate in undergraduate study & .429 & .303 & 2.006 & 1 & 0.157 & 1.536 \\
\hline Fixed & -6.585 & 1.083 & 36.983 & 1 & 0.000 & 0.001 \\
\hline
\end{tabular}

$\beta=-.239 \quad$ Standard error $=.114 \quad$ Wald $=4.381 \mathrm{SD}=1 \quad \mathrm{p}=.036 \operatorname{Exp}(\beta)=.787$

Cox-Snell $\mathrm{R}^{2}=.368$, Nagelkerke $\mathrm{R}^{2}=.368$

\section{DISCUSSION}

This study's findings aiming to identify the readiness and the affecting factors of the final year nursing students are discussed in this section. Of the nursing students, $56.2 \%$ said that they were ready for nursing. Yang and Jiang found that nursing students who were in the final stage of clinical practical training had medium professional competence (Yang and Jiang, 2014) and felt well about their profession (Lofmark et al., 2006). They had high readiness rates for clinical practical training (Woods et al., 2013). Nursing students felt a good level of professional competence (Kajander-Unkuri et al., 2014), most of them felt ready for the profession (Nash et al., 2009). They have high readiness perceptions for practical training in nursing (Brown, 2016), and they were not sufficiently prepared for the reality of the clinical setting before starting work (Kajander-Unkuri et al., 2014). On the other hand, Morrell and Ridgway found that lecturers deemed nursing students' readiness for the profession to be insufficient (Morrell and Ridgway, 2014). Our study found that the readiness perceptions of nursing students were at a medium level, which is lower than they are in some other studies. This difference may be due to the lecturers, the students and the practical training schedule.

Students' having selected the profession willingly and being happy to have done so are predictor variables for readiness for nursing. Those who selected the profession willingly were two times more adjusted to nursing than those who did not. Similarly, those who felt happy to have selected the profession were two times more adjusted than those did not. Woods et al. (2015) found that students' being happy to have selected the profession affected their readiness for nursing, and Numminen et al. (2015) found that newly graduated nurses' satisfaction with and commitment to the profession affected their nursing qualifications. Studies of newly graduated nurses indicate that being satisfied to have selected the profession affected their proficiency (Ulrich et al., 2010; Bratt and Felzer, 2011; Tastan et al., 2013). This study also found that the students who selected willingly and were satisfied with the profession were more ready for nursing than the others. This result shows that individual and intrinsic features of nursing students affected readiness for the profession.

Feeling safe in the profession affects readiness of the students for nursing. Cooper et al. (2005) found that nursing students felt safe in the profession towards the end of their education, and this affected their readiness for the profession. Usher et al. found that their feeling safe in the profession affected their readiness (Usher et al. 2015). Other studies have found that nursing students' awareness about their future professional responsibilities caused them to feel unsafe (Jarvinen et al., 2018; Ross and Clifford, 2002; Carlson, et al., 2005). Our research finding shows parallelism with the literature. The students who felt well-equipped in terms of knowledge and skills felt safe and thus, ready for the profession. This study found that self-efficacy for the profession was a predictor of readiness for the profession, and those who felt self-efficacy for the profession were nearly three times more adjusted to nursing than those did not. Morrell and Ridgway (2014) and Järvinen et al. (2018) found that one important factor in students' readiness for the profession was professional competence, and that students with high professional competence were more adjusted to nursing (Bowdoin, 2014). Christensen et al. (2016) found that final year nursing students doubted their professional competence, and Usher et al. (2015) found that nursing students' self-efficacy for invasive operations affected their readiness for the profession. Missen et al. (2015) found in their study on the coordinators of graduate nursing students that the lack of clinical skills affects professional readiness. Nursing students' readiness for the profession is also related to the extent to which they think they have the competencies that are expected of them. Consequently, the readiness of nursing students who felt qualified for the profession was found to be high, as it is in the literature.

This study found that students' concerns about professional life were a predictor of their readiness for the profession. The students with concerns about their professional life were about half more ready for nursing than those who did not have concerns. Morrell and Ridgway (2014) and Andrews (2013)found that the concerns of nursing students about their professional life affected their readiness, and Wolff et al.(2010) found that nursing students' worries 
about professional life affected their readiness. In addition, Missen et al. (2015) found that the anxiety of working in a permanent job affects professional readiness in graduate nursing students. Like the literature, this study found that feeling anxious affected students' readiness for the profession. Feeling anxiety concerning working life is a student-based internal factor. However, since final year students have had clinical experience during their undergraduate education, the factors that increase anxiety may be due to lecturers, clinical processes, nursing policies and the guidance skills of nurse colleagues. This study found that nursing students' thoughts about nursing affected their readiness for the profession. Nursing students' intention of leaving the profession also affect their readiness (Flinkman, 2014) and their competency (Ishihara et al., 2014). Casey et al. found that one of the reasons for leaving nursing was feeling insufficiently prepared for the profession (Casey et al, 2011). Like the literature, this study found that the students with thoughts about nursing were more adjusted to the profession.

This study found that finding their practical training adequate affected the students' readiness for nursing. Students' lack of professional readiness is about nursing education (Wolff et al., 2010) and the main educational factor that affects their readiness is clinical practical training (Jarvinen et al., 2018). Their readiness is affected by intensive clinical experience (Casey et al., 2011). Since nursing is a clinical profession, students' finding practical training adequate affects their readiness. Their anxiety levels fall and their problemsolving skills increase as their practical training increases. Practical training increases students' self-confidence and sense of belonging to the profession. This study found that the nursing students' internships and summer internships did not affect their readiness for the profession. Students' readiness for nursing in non-traditional education systems is higher than others (Brown, 2016). Students who spend their final year in a clinic are more adjusted to the profession (Watt and Pascoe, 2013), and students who do simulation training are more adjusted to professional life (Woods et al., 2015). Unlike the literature, this study found that internships and summer internships do not affect readiness for the profession, and that the education of most of the study group in a conventional system without internships or summer internships was effective.

\section{CONCLUSION}

This study found that half of the students felt ready for the profession. Students' readiness for the profession and their having selected the profession willingly, being happy to have selected the profession, feeling safe in the profession, selfefficacy for the profession, feeling anxiety concerning working life, thoughts about nursing and finding practical training adequate in undergraduate study affected their readiness for nursing. These results suggest that: theoretical courses in the education of nursing students should involve methods and techniques that facilitate learning and support skills acquisition, students should be supported by effective clinical practical training, lecturers should have an active role in clinical practical training, the professional concerns of students and the affecting factors should be identified, measurement and evaluation systems that will evaluate professional readiness levels of final year students after graduation should be used and accordingly, the training program should be revised.

\section{REFERENCES}

Andrews, D. R. (2013). Expectations of millennial nurse graduates transitioning into practice. Nursing Administration Quarterly, 37(2), 152-159.

Bowdoin, C. (2014). Thinking like a nurse and perceived readiness for professional practice: A mixed methods study. Mercer University.

Bratt, M. M., \& Felzer, H. M. (2011). Perceptions of professional practice and work environment of new graduates in a nurse residency program. The Journal of Continuing Education in Nursing, 42(12), 559-568.

Brown, H., D. (2016). Examination of baccalaureate nursing students' readiness for practice. Thesis dissertation, Colorado State University-Pueblo Graduate Faculty, Pueblo, $\mathrm{CO}$.

Carlson, S., Kotze, W. J., \& Van Rooyen, D. (2005). Experiences of final year nursing students in their preparedness to become registered nurses. Curationis, 28(4), 65-37.

Casey, K., Fink, R., Jaynes, C., Campbell, L., Cook, P., \& Wilson, V. (2011). Readiness for practice: The senior practicum experience. Journal of Nursing Education, 50(11), 646-652.

Christensen, M., Aubeeluck, A., Fergusson, D., Craft, J., Knight, J., Wirihana, L., \& Stupple, E. (2016). Do student nurses experience Imposter Phenomenon? An international comparison of Final Year Undergraduate Nursing Students readiness for registration. Journal of advanced nursing, 72(11), 2784-2793.

Cooper, C., Taft, L. B., \& Thelen, M. (2005). Preparing for practice: Students' reflections on their final clinical experience. Journal of Professional Nursing, 21(5), 293-302.

Duchscher, J. B. (2008). A process of becoming: The stages of new nursing graduate professional role transition. The Journal of Continuing Education in Nursing, 39(10), 441450.

Erdoğan, S., Nahcivan, N., \& Esin, M. (2014). Research process, application and critics in nursing. Nobel Tip, Ankara.

Flinkman, M. (2014). Young registered nurses' intent to leave the profession in Finland-a mixed-method study.

Ishihara, I., Ishibashi, Y., Takahashi, K., \& Nakashima, M. (2014). Effect of organizational factors and work environments on newly graduated nurses' intention to leave. Japan Journal of Nursing Science, 11(3), 200-210.

Järvinen, T., Eklöf, N., \& Salminen, L. (2018). Factors related to nursing students' readiness to enter working life-A scoping literature review. Nurse education in practice, 29, 191-199.

Kajander-Unkuri, S., Meretoja, R., Katajisto, J., Saarikoski, M., Salminen, L., Suhonen, R., \& Leino-Kilpi, H. (2014). Self-assessed level of competence of graduating nursing students and factors related to it. Nurse Education Today, 34(5), 795-801.

Lofmark, A., Smide, B., \& Wikblad, K. (2006). Competence of newly-graduated nurses-a comparison of the perceptions of qualified nurses and students. Journal of Advanced Nursing, 53(6), 721-728. 
Missen, K., McKenna, L., \& Beauchamp, A. (2015): Work readiness of nursing graduates: current perspectives of graduate nurse program coordinators, Contemporary Nurse, 51(1):27-38.

Morrell, N., \& Ridgway, V. (2014). Are we preparing student nurses for final practice placement?. British journal of nursing, 23(10), 518-523.

Nash, R., Lemcke, P., \& Sacre, S. (2009). Enhancing transition: An enhanced model of clinical placement for final year nursing students. Nurse Education Today, 29(1), 48-56.

Numminen, O., Leino-Kilpi, H., Isoaho, H., \& Meretoja, R. (2015). Newly graduated nurses' competence and individual and organizational factors: A multivariate analysis. Journal of Nursing Scholarship, 47(5), 446-457.

Porter, J., Morphet, J., Missen, K., \& Raymond, A. (2013). Preparation for high-acuity clinical placement: confidence levels of final-year nursing students. Advances in medical education and practice, 4,83 .

Ross, H., \& Clifford, K. (2002). Research as a catalyst for change: the transition from student to registered nurse. Journal of Clinical Nursing, 11(4), 545-553.

Şengül, F. (2010). The impact of nursing education models on critical thinking trends of students: Multi-centered work. Thesis dissertation, Cukurova University, Institute of Health Sciences Nursing Department, Adana.

Topses, G. (2003). Developmental and learning psychology. Istanbul: Nobel Academic Publishing.

Tastan, S., Unver, V., \& Hatipoglu, S. (2013). An analysis of the factors affecting the transition period to professional roles for newly graduated nurses in $\mathrm{T}$ urkey. International nursing review, 60(3), 405-412.
Ulrich, B., Krozek, C., Early, S., Ashlock, C. H., Africa, L. M., \& Carman, M. L. (2010). Improving retention, confidence, and competence of new graduate nurses: Results from a 10-year longitudinal database. Nursing economics, 28(6), 363.

Usher, K., Mills, J., West, C., Park, T., \& Woods, C. (2015). Preregistration student nurses' self-reported preparedness for practice before and after the introduction of a capstone subject. Journal of Clinical Nursing, 24(21-22), 3245-3254.

Watt, E., \& Pascoe, E. (2013). An exploration of graduate nurses' perceptions of their preparedness for practice after undertaking the final year of their bachelor of nursing degree in a university-based clinical school of nursing. International Journal of Nursing Practice, 19(1), 23-30.

Wolff, A.C., Regan, S., Pesut, B., \& Black, J. (2010). Ready for what? An exploration of the meaning of new graduate nurses' readiness for practice. International Journal of Nursing Education Scholarship, 7(1).

Woods, C., West, C., Mills, J., Park, T., Southern, J., \& Usher, K. (2015). Undergraduate student nurses' selfreported preparedness for practice. Collegian, 22(4), 359-368.

Woods, C., Usher, K., Mills, J., West, C., \& Park, T. (2013). Final year student nurses' readiness for practice. Annals of the Australasian College of Tropical Medicine, 14, 16-16.

Yang, G. F., \& Jiang, X. Y. (2014). Self-directed learning readiness and nursing competency among undergraduate nursing students in Fujian province of China. International Journal of Nursing Sciences, 1(3), 255-259. 